\title{
The Royal Asiatic Society Award 2001
}

At the start of the millennium Council reviewed medals and prizes and decided to discontinue the Gold Medal (which had not in any case been awarded for some time) and establish in its place the Society's Award. This Award will be made every two or three years in recognition of outstanding scholarship in Asian studies. Having considered a number of tenders, Council commissioned Ms Danuta Solowiej-Wedderburn to design and cast a medal bearing versions of two of the original Daniell images: the elephant and howdah on one side and the banyan-tree on the other (see John Hansman, "The Emblems, Medals and Medallists of the Royal Asiatic Society", JRAS [I984 Part I], pp. 99-II9. Council approved the nomination of Mr John M. Gullick, who was recommended by a search committee (chaired by the Director) to be the first recipient of the RAS Award. On Io January 2002 the President presented the RAS Award for 200I to Mr Gullick who replied with a lecture, "An Indian official in Singapore: Governor Cavanagh (I859-I867)".

Soldier, administrator and scholar, with careers in colonial government, business and law, John Gullick has made a major contribution to our knowledge and understanding of the Malay world. Born in I9I6, he was educated at Taunton School and Christ's College, Cambridge, where he held an open major scholarship and graduated with a double first in Classics in 1939. He then entered the Colonial Administrative Service, but, before he could take up a post in Uganda, he was called for military service (1940-46). After serving in the Ethiopian campaign and in military administration in East Africa and the Middle East, he landed in Malaya in September 1945 as part of the reoccupation force which established the British Military Administration following the Japanese surrender. Demobilised with the rank of lieutenant colonel, John Gullick was appointed to the Malayan Civil Service. He worked both in the state of Negri Sembilan and in the federal secretariat in Kuala Lumpur. During the Malayan Emergency and the preparations for Malayan independence, his tasks included servicing three major initiatives: the Rural and Industrial Development Authority headed by Dato Onn bin Jaafar, the UK Police Mission to Malaya and Tunku Abdul Rahman's committee for the Malayanisation of public services.

Retiring from Malayan government just before the country became independent in 1957, John Gullick was appointed secretary to the Guthrie group of plantation companies, chaired by the formidable Sir John Hay. He became a chartered (company) secretary in I960 and then turned to a career in law. John had been called to the bar in I953, though later resigned in order to qualify as a solicitor. From I964 to I974 he worked in a City law 
firm, rising to become the senior partner. Yet another career opened up in the mid-I970s when for the next dozen years he worked as a freelance lecturer in company law and practice. John Gullick's immense experience and skills in so many walks of public life were keenly sought by others: in the I970s he served as deputy chairman of the governors of the London School of Economics, and, from 1972 to I983, he was a non-executive director of the parent company of the Guthrie group.

From the moment John landed on the beach at Morib as part of Operation Zipper for the liberation of Malaya in September 1945, he made it his business to learn the language and gain an understanding of the culture of the Malay people. This business became a passion. Thus, during leave from Malaya in the 1950s, he studied at the LSE under Professor (later Sir Raymond) Firth and Professor Maurice Freedman, obtaining a London postgraduate diploma in social anthropology with distinction. His dissertation formed the basis for his first, pioneering monograph, Indigenous Political Systems of Western Malaya. This was published in 1958 , was republished in Malay in 1970 and came out in a revised edition in 1988. Examining history from the perspective of a social anthropologist, John Gullick has produced over I4 books and numerous scholarly articles. In addition to Indigenous Political Systems, perhaps the most notable amongst his books have been Malay Society in the Late Nineteenth Century: The Beginnings of Change (1987) and Rulers and Residents: Influence and Power in the Malay States 1870-1920 (1992). His development of historical anthropology has shaped the research of successive generations of scholars working in the fields of the social and cultural history of the Malay world. Indeed, John Gullick has been immensely generous with his time, knowledge and resources in assisting younger scholars. He is an indefatigable correspondent, replying comprehensively and by return to any query that comes his way. Over the years he has regularly served as a $\mathrm{PhD}$ examiner for the Centres of SE Asian Studies at SOAS, Hull and Kent, and for decades he has been a leading figure in the Malayan (later Malaysian) Branch of the Royal Asiatic Society, acting as its UK representative since the early I 980 os.

John Gullick is the embodiment of the virtues, and his work fulfils the aspirations, of those scholar-administrators who founded our Society and of those who went on to advance its objectives and establish branches throughout Asia. His scholarship has received international recognition, not least amongst the academic community of Malaysia. The RAS Award for $200 \mathrm{I}$ was presented to John in recognition of his outstanding contribution to knowledge and understanding of the Malay world.

A. J. Stockwell 